\title{
ANALYSIS OF THE DOMESTIC LEGAL FRAMEWORK IN RELATION TO THE RIGHT TO HEALTH FOR INTERNALLY DISPLACED PERSONS IN SRI LANKA
}

\author{
Wickramage Kolitha ${ }^{1}$ and Senavirathne Wasantha ${ }^{2}$ \\ ${ }^{1}$ Head, Health Programs, International Organization for Migration, Sri Lanka. \\ ${ }^{2}$ Senior Lecturer, Faculty of Law and Faculty of Graduate Studies, \\ University of Colombo, Sri Lanka.
}

\begin{abstract}
We critically examine Sri Lanka's current legal framework to examine the extent to which the 'right to health' is stipulated specifically for those conflict affected internally displaced persons (IDPs) living within IDP camp settings. Understanding the domestic legal frameworks pertaining to the right to health may be useful for those professionals working at the nexus of legal medicine and human rights in Sri Lanka and advancing gaps in knowledge in this area.
\end{abstract}

\section{INTRODUCTION}

\section{Human Rights as they relate to the Right to Health}

A "human rights-based approach" recognizes that every human being, by virtue of his or her birth as a human being, is a holder of rights. Human rights are therefore an obligation on the part of the Government to respect, protect and fulfill these rights. The United Nations supports its Member States in progressively realizing the right to health for all is thus a legal and moral obligation incumbent on all members of the international community. Today, the right to the enjoyment of the highest attainable standard of physical and mental health is at the centre of the achievement of the Millennium Development Goals (MDGs) - a major effort by global community to eradicate extreme poverty. Goals 4,5 and 6 specifically relate to health. The human right to health is firmly recognized in numerous international instruments under the Normative Framework. For instance, Article 25(1) of the Universal declaration of human rights (UDHR) while non-binding affirms, "everyone has a right to a standard of living adequate for the health of himself and his family, including food, clothing, housing, and medical care and necessary social services."

The ICESCR provides the most comprehensive article on the right to health in international human rights law. According to article 12(1) of the Covenant, States Parties recognize "the right of everyone to the enjoyment of the highest attainable standard of physical and mental health", while article 12(2) enumerates, by way of illustration, a number of "steps to be taken by the States Parties to achieve the full realization of this right". ICESCR has been ratified by 145 countries, including Sri Lanka (as of May 2002). In May 2000, the Committee on Economic, Social and Cultural Rights, which monitors the Covenant, adopted a General Comment on the right to health. General Comments serve to clarify the nature and content of individual rights and States Parties' (those states that have ratified) obligations. The General Comment recognized that the right to health is closely related to and dependent upon the realization of other human rights, including the right to food, housing, work, education, participation, the enjoyment of the benefits of scientific progress and its applications, life, non-discrimination, equality, the prohibition against torture, privacy, access to information and the freedoms of association, assembly and movement. Further, the Committee interpreted the right to health as an inclusive right extending not only to timely and appropriate health care but also to the underlying determinants of health, such as access to safe and potable water and adequate 
sanitation, an adequate supply of safe food, nutrition and housing, healthy occupational and environmental conditions and access to healthrelated education and information, including on sexual and reproductive health.

General Comment 14 acknowledges the importance of the underlying determinants of health by stating that the right to health is dependent on, and contributes to, the realization of many other human rights, such as the rights an adequate standard of living, privacy and access to information. General Comment 14, contains both freedoms and entitlements. Freedoms include the right to be free from nonconsensual medical treatment (this has especially been invoked on interventional studies and psychiatric treatments), torture and other cruel, inhuman or degrading treatment or punishment, and the right to control one's body, including sexual and reproductive freedom.

Entitlements include the right to a system of health protection; the right to prevention, treatment and control of diseases; the right to healthy natural and workplace environments; and the right to health facilities, goods and services. Participation of the population in health-related decision-making at the national and community levels is another important entitlement. Non-discrimination and equality are critical components of the right to health. States have an obligation to prohibit discrimination and ensure equality to all in relation to access to health care and the underlying determinants of health. States must recognize and provide for the differences and specific needs of population groups, such as women, children, or persons with disabilities, which generally face particular health challenges, such as higher mortality rates or vulnerability to specific diseases. General Comment 14 sets out four criteria by which to evaluate the right to health: a) Availability to allow Functioning public health and health facilities, goods and services, as well as programmes, have to be available in sufficient quantity; b) Accessibility of Health facilities, goods and services have to be accessible to everyone without discrimination, within the jurisdiction of the State party; c) Acceptability of all health facilities, goods and services must be respectful of medical ethics and culturally appropriate, sensitive to gender and life-cycle requirements, as well as being designed to respect confidentiality and improve the health status of those concerned; and, d) Quality of Health facilities, goods and services must be scientifically and medically appropriate and of good quality.

The right to health is a fundamental human right, yet there is opportunity for States to limit their responsibilities to exercise public health protection. The Covenant's limitation clause, article 4, is primarily intended to protect the rights of individuals rather than to permit the imposition of limitations by States. A State party for example can "restrict the movement of, or incarcerates, persons with transmissible diseases such as HIV/AIDS, refuses to allow doctors to treat persons believed to be opposed to a government, or fails to provide immunization against the community's major infectious diseases, on grounds such as national security or the preservation of public order", has the burden of justifying such serious measures in relation to each of the elements identified in article 4. As elaborated in article 5.1, such limitations by a State must be proportional. Proportionality means that measures must be least restrictive with alternatives adopted, they should be of limited duration and subject to review by UN Human Rights Council.

Additionally, the right to health is recognized, inter alia, in the CERD of 1963, the CEDAW of 1979 and in the CRC of 1989. Several regional human rights instruments also recognize the right to health, such as the European Social Charter of 1961 as revised, the African Charter on Human and Peoples' Rights of 1981 and the Additional Protocol to the American Convention on Human Rights in the Area of Economic, Social and Cultural Rights of 1988 (the Protocol entered into force in 1999). Similarly, the right to health has been proclaimed by the Commission on Human Rights and further elaborated in the Vienna Declaration and Programme of Action of 1993 and other international instruments. 


\section{New trends and developments in international legal framework pertaining to health and human rights}

In recent years, there have been considerable developments in international law with respect to the normative definition of the right to health, which includes both health care and healthy conditions (Yamin, 2005). These norms offer a framework that shifts the analysis of issues such as disparities in treatment from questions of quality of care to matters of social justice. When assessing the new additions to the international legal framework, there appears to be a trend towards a more inclusive definition of the right to health for specific segments of the population, most notably children and disabled persons, and within specific contexts.

For instance, The Convention on the Rights of the Child was adopted and opened for signature, ratification and accession by General Assembly resolution $44 / 25$ of 20 November 1989. It entered into force 2 September 1990, in accordance with article 49. The Children's Convention have some powerful provisions regarding child health, yet to help stem the growing abuse and exploitation of children worldwide, in 2000 the United Nations General Assembly adopted two Optional Protocols to the Convention to increase the protection of children from involvement in armed conflicts and from sexual exploitation. First was the Optional Protocol to the Convention on the Rights of the Child on the sale of children, child prostitution and child pornography, adopted and opened for signature, ratification and accession by General Assembly resolution A/RES/54/263 of 25 May 2000, entry into force on 18 January 2002. Second was the Optional Protocol to the Convention on the Rights of the Child on the involvement of children in armed conflict, adopted and opened for signature, ratification and accession by General Assembly resolution A/RES/54/263 of 25 May 2000, entry into force 12 February 2002. The fact that special emphasis was provided to child wellbeing in conflict settings is indicative of a trend towards context specific and focus on specific vulnerable groups in the population.

More recently, the United Nations passed a resolution protecting the rights of disabled persons that is also indicative of the trend in focusing on specific vulnerable groups and recognizing the unique health, developmental and economic challenges these groups face in society. The Convention on the Rights of Persons with Disabilities is an international human rights treaty of the United Nations intended to protect the rights and dignity of persons with disabilities. The Convention which opened for signature on 30 March 2007 became one of the most quickly supported human rights instrument in history, with strong support from all regional groups. 155 States signed the Convention upon its opening in 2007 and 126 States ratified the Convention within its first five years (UN, 2012). Article 25 provides explicit protection on health grounds specifying that "persons with disabilities have the right to the enjoyment of the highest attainable standard of health without discrimination on the basis of disability", with "States Parties shall take all appropriate measures to ensure access for persons with disabilities to health services that are gendersensitive, including health-related rehabilitation. Highly relevant to the research question posed in this thesis, was the emphasis the 2007 Convention placed on rights of disabled persons in situations of humanitarian emergencies. Article 11 of the convention on 'Situations of risk and humanitarian emergencies' stipulates that States Parties shall take, in accordance with their obligations under international law, including international humanitarian law and international human rights law, all necessary measures to "ensure the protection and safety of persons with disabilities in situations of risk, including situations of armed conflict, humanitarian emergencies and the occurrence of natural disasters".

The review of international frameworks in this chapter have also revealed potential weaknesses in enabling health protection of civilians affected by conflict - that of the role of health professionals. In times of armed conflict and in post-conflict situations, civilian hospitals, medical facilities and health and medical staff may themselves become targets of war. Ensuring health protection requires steps not only to safeguard the lives of health workers involved in responding to humanitarian crises, 
but also ensuring the enabling environment is created for them to practice effectively. Essential to the human rights perspective of health are the obligations of the State and nonstate actors in protecting the health care workers/health system in order to ensure the fulfillment of the individual's right to health. Health protection can also be enabled if the professionals responsible for the health care system are well trained, capacitated and committed to universal ethical principles and professional standards. The state is therefore responsible to establish and secure an enabling environment for health professionals to undertake interventions.

Indeed in 2002 the UN Member States at the 55th World Health Assembly in Geneva adopted a resolution WHA55 entitled "Health and medical services in times of armed conflict" (WHA, 2002), to protect medical missions and to enforce the protection of healthcare during conflict settings. Whilst the resolution was recognized as supportive of the Geneva Conventions to enforce the protection of healthcare during armed conflict, many human rights organizations and advocates called for the leadership by WHO to develop practical methods and mechanisms for the documentation of all violations of international humanitarian law against patients, health workers, facilities, and transports and to provide guidance to member States in how to increase protection of health functions in zones of armed conflict. Indeed a coalition called "Safeguarding Health in Conflict Coalition" formed by aid organizations such as Doctors for Human Rights, International Council of Nurses and Physicians for Human Rights and other, advocated to WHO to urge passage of a new resolution-requiring the WHO to lead international data-collection of attacks on health workers, facilities, transports, and patients (Intra-health, 2012). At the 65th World Health Assembly in Geneva in May 2012, WHO member states adopted a resolution requiring the WHO to lead international data collection on attacks involving health workers, facilities, transportation and patients during armed conflicts (WHA, 2012). The Safeguarding Health in Conflict coalition also appealed to WHO to ensure there is domestic and international prosecution of those responsible for intentional attacks on healthcare facilities, health workers, patients and the transport systems for providing drugs and medical supplies, which constitute war crimes under the laws of war (IHPI, 2012). This latter proposal however has yet to be adopted, with robust systems of accountability, with consequences for non-compliance of the resolutions still not enshrined by member states (Rubenstein, 2012).

The emergence of global epidemics such as SARS in 2003 and the implications of multinational corporations in influencing the health of populations such as the Tobacco and Pharmaceutical industries, have highlighted the urgent need to reform national public health laws and international obligations relating to public health in order to meet the new realities of a globalized world (Sohn, 2012). For instance, the WHO Framework Convention on Tobacco Control (2003) was a direct response to the need to ensure the right to health of all populations at risk of cancer and other morbidities due to cigarette smoke, and the revision of the WHO International Health Regulations in 2005 which provides a legal basis for the control and prevention of communicable diseases. Although discussions on such developments go beyond the scope of this thesis focused on a post-war health sector humanitarian response, such trends are expected to lead to enhancements within the existing international human rights instruments/ policy landscape.

In this analysis of normative frameworks, it also becomes apparent that there are complex linkages between health and human rights (WHO, 2002). The right to health is interrelated with, and expressed implicitly and explicitly in numerous articles. To speak of health in isolation of other rights then becomes futile. These inter-relationships, graphically presented in Figure 1, show the protection of specific rights of IDPs during disasters and their connection with the normative frameworks. Therefore the right to health operates directly or indirectly as a prerequisite to all other human rights recognized in treaties. To deny someone health care is to deny or damage all that individual's rights. Without health, individuals are denied their right to be contributing members of the community and 
to provide for their families. Individuals who lack adequate health care can thus lose some or all ability to exercise fully the civil, political, economic, social, and cultural rights they possess. As Perrin in his analysis of The Right to Health in Armed Conflict articulates, the protection of the right to health requires the complement of the entire legal framework; " While IHL integrates specific considerations, striking a balance between humanitarian considerations and military necessity, human rights law remains relevant to complement IHL in order to fill the potential gaps" (Perrin, 2009).

Finally, the SPHERE Standards were presented as an important and practical resource/tool to guide Governments and humanitarian actors to ensure the Right to Health is realized for disaster affected populations. However, it is important to point out that the SPHERE standards reflect the minimum standards and package of essential live saving care. What should aimed for is not the minimum, rather to achieve the realization of the entire complement of care afforded to other non-displaced members of the society.

\section{The rights of internally displaced persons}

All persons are entitled to enjoy, equally and without discrimination, the same rights and freedoms under international and national law. There are various bodies of International law that provide a comprehensive International legal framework for protection in all situations, including those during armed conflict. However, there are three bodies of law that provide a legal framework for protection in all situations of internal displacement: International human rights law (IHR), International humanitarian law (IHL), and finally International criminal law (ICL). A fourth element is also considered: "The Guiding Principles on Internal Displacement" (GPID). While the GPID is not a law, it sets out the rights of IDPs and the responsibilities of States and other authorities towards them. Other internationally developed instruments, guides and standard operational principals and articulate the right to health for displaced populations. These include the SPHERE Project which sets a Humanitarian Charter and
Minimum Standards in humanitarian intervention, and Codes of Conduct enshrined in individual agencies such as those International Red Cross \& Red Crescent Movement.

\section{Duty to Protect in reference to Internally Displaced Persons (IDPs)}

Internally Displaced Persons (IDP) are defined as persons who are uprooted for reasons of war, disaster or persecution, and move within the borders of their own nations ${ }^{1}$. During the three decades of armed conflict between the Sri Lankan armed forces and the Liberation Tigers of Tamil Eelam (LTTE), it is estimated that over a million people were displaced. As of the end of September 2012, more than 115,000 internally displaced people (IDPs) were still living in camps, with host communities or in transit sites, or had been relocated to areas other than their places of origin in Sri Lanka ${ }^{2}$.

Refugees, by definition, are outside of their country of nationality or habitual residence ${ }^{\mathrm{i}}$. Both categories of displaced persons often face similar risks and deprivations. Unlike IDPs however, refugees have a legal status under international law. IDPs are primarily the responsibility of the state and come under the purview of state law. This has resulted in many debates being raised as to the level of international community's involvement in IDP crisis. IDPs depend on the state for protection and assistance. IDPs' fundamental rights and freedoms and economic and political freedoms are often compromised. Therefore the protection needs and risks of this sector are generally higher than those of the general population. Involuntary departure and the fact that the individual remains within his/her country are the two defining elements of an internally displace person (IDP).

\footnotetext{
'A refugee is defined as a person who owing to a wellfounded fear of being persecuted for reasons of race, religion, nationality, membership of a particular social group or political opinion, is outside the country of his/her nationality or habitual residence, and is unable, or owing to such fear, is unwilling to avail himself/herself of the protection of that country. See Art. 1 of the 1951 Convention Relating to the Status of Refugees.
} 
Figure 1 adapted from the WHO, shows the required multi-sectoral approach for protecting the health rights of IDPs (Bile et al., 2011). As summarized in Figure 1, the right to health for IDPs, lie at the fulcrum of the right to life, economic, social and cultural rights and civil and political rights. It therefore highlights internal displacement as a core human rights problem, and not merely a humanitarian issue that requires humanitarian response. Internal displacement violates civil and political as well as economic, social and cultural rights.

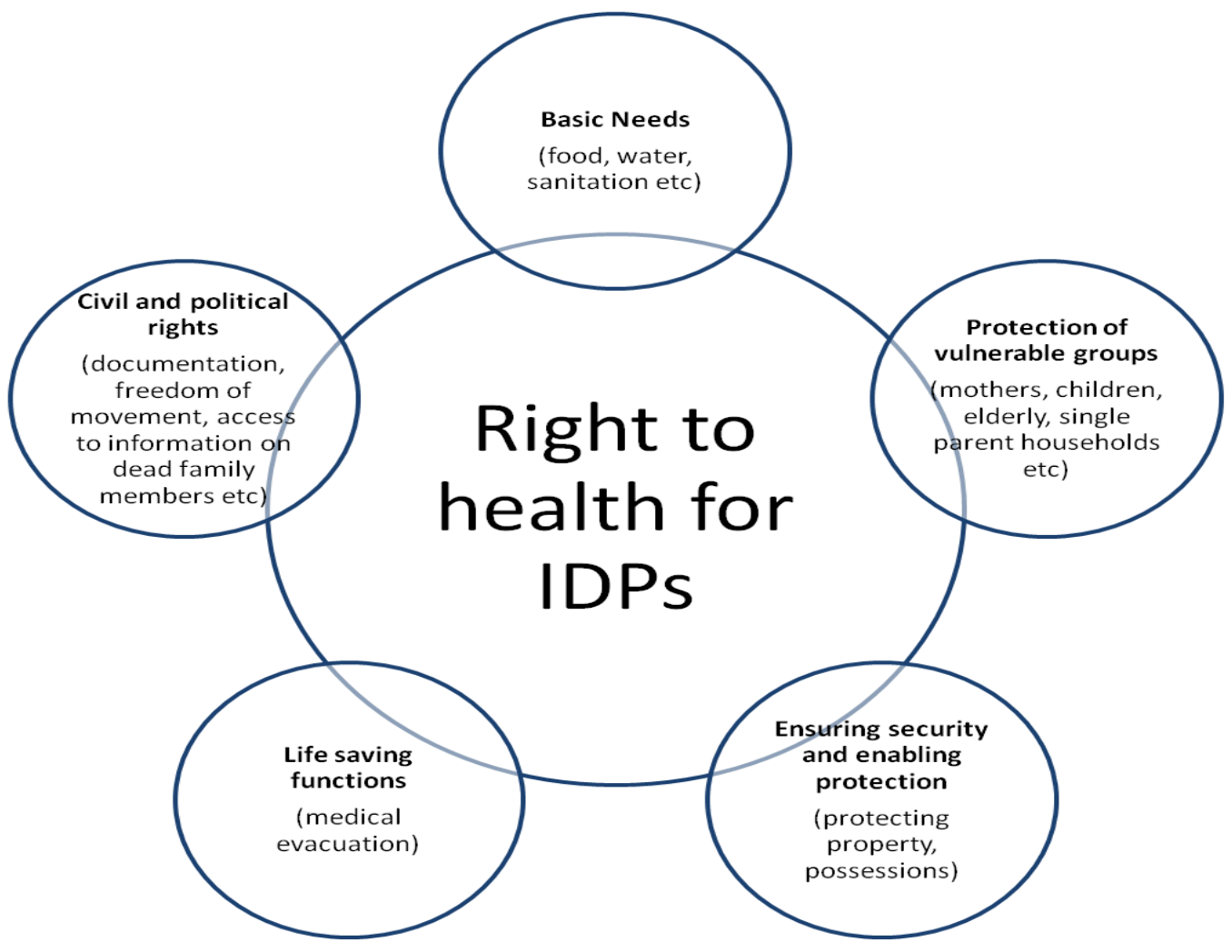

Figure 1 - Protection of specific human right during disasters and their connection with health rights

Each State bears the primary responsibility for protecting internally displaced persons, and all persons within their own country. National responsibility is a core concept of any response to internal displacement. The role of the international community cannot directly affect the protection of IDPs since IDPs are a function of state sovereignty. Even as governments themselves may act as perpetrators of violence, and human rights violations against their own citizens, the role of international actors is to reinforce, not replace, national responsibility ${ }^{\text {ii }}$. The State must not only ensure the protection of rights in accordance with international law, but responsibly enable indigenous strategies and domestic legal protections in situations of

\footnotetext{
ii In situations of armed conflict, both State and non-State actors, have a responsibility to respect and ensure respect for international humanitarian law, including by providing protection and assistance to the civilian population.
}

internal displacement. The international strategic framework entitled Addressing Internal Displacement - Framework for National Responsibility sets 12 key actions for states to implement in relation to IDP protection $^{3}$. Today it forms a sort of 'checklist' for protection of IDPs and gauge responses by the State. In addition to entailed is contained in the 12 elements. This framework will be applied in later chapters as an attempt to determine the extent to which the Sri Lanka authorities ensure the right to health for those Internally Displaced in the aftermath of the most recent civil conflict.

\section{Domestic Legal Framework in Sri Lanka}

The Government of Sri Lanka (GoSL), with its dualist system of law making has a responsibility to ensure that their national laws and policies respect and reflect their obligations 
under international law, including those contained in international human rights and humanitarian law. More specifically, national legislative and policy frameworks should respect the rights and guarantees to which IDPs are entitled under international law, and be consistent with Sri Lanka's international legal obligations. IDP Protection strategies and activities should also take into account relevant domestic traditional, customary, or religious dispute resolution mechanisms.

While the local laws are applicable to IDPs, the analysis below provides evidence that there is no policy coherence, and in some cases, "nonprogressives' in legislation to address the right to health of the displaced. Further, there is no overarching national legal framework that specifically and holistically refers to right to health for those internally displaced. The result of this is that IDPs may be deprived of their rights and marginalized of their agency and aspiration. Thus, in Sri Lanka, existing health provisions applicable to IDPs are scattered in an unsystematic manner, with little cohesion. Nonetheless, the rights of IDPs are partially secured by approximately 11 existing national laws/acts described in detail below. Of these, the vast majority were created between 2002 and 2007.

Though the Right to Health it is not directly stipulated as a Constitutional right, there are instruments in Sri Lankan fundamental rights field that may be evoked. According to the Article 12 (1) of Constitution, "all persons are equal before the law and are entitled to the equal protection of the law. Therefore, special mechanisms, if the situation requires should be provided to uplift their rights because different qualities of health standards for persons residing in different geographic locations may constitute discrimination under the Article 12 of Sri Lankan Constitution. Common laws that apply to all states citizens are also invoked in protecting IDP rights. Statutes like Penal Code, Food Act, Health Service Act and provincial statues on health service have specifically laid down provisions to maintain and preserve public health. IDPs too, are entitled to these constitutional and statutory rights, with no distinctions to their status as IDPs. The discussion below analyses the domestic legal framework in ensuring the right to health of internally displaced persons in Sri Lanka.

\section{The Sri Lankan Constitution}

The Fundamental Rights Chapter 3 of the Sri Lankan Constitution ${ }^{\text {iii }}$ does not explicitly express and recognize the right to health. As described earlier, the only reference given to health is as a suspension or derogation where Article 7 of the Fundamental Rights of the constitution states, "in the interests of national security, public order and the protection of public health..." the state may withhold rights. The Sri Lankan Constitution guarantees that "(1) All persons are equal before the law and are entitled to the equal protection of the law", and, (2) "No citizen shall be discriminated against on the grounds of race, religion, language, caste, sex, political opinion, place of birth or any such grounds".

Even though there is no explicit statement in the Constitution of Sri Lanka on the right to health, the constitution does clearly articulate the right to life in Articles 11 and 13.4 of the constitution. This inalienable right of life is indeed a pragmatic link to the right to health since there is no life without health. Therefore it may also be argued that the right to health is protected under the Sri Lankan Constitution because the right to life would be meaningless without it.

A prime example where the right to life clause has enabled the right to health is seen by the land mark decision of Justice Mark Fernando made in the Supreme Court in the case of Sanjeewa, AAL (on behalf of G.M.Perera) V Suraweera, OIC, Wattala and others, where he cited the Article 12 of the ICESCR ${ }^{\text {iv }}$. The bench ruled in this case that "citizens have the right to choose between state and private medical care to save one torture victim's life". Justice Mark Fernando submitted that the infringement of a right to health can be justifiable under the Sri

\footnotetext{
iii A constitutional right is a legal right granted by a sovereignty's constitution to its citizens and possibly others within its jurisdiction.

iv Silva v Iddamalgoda 20032 SLR 63, Rani Fernando v OIC Seeduwa Police, SC/FR/700/2000,SCMinutes 26.07.2004 and described in paper by Dissanayake, S (2009) "Right to Health" of Internally Displaced Persons, Human Rights Commission of Sri Lanka.
} 
Lankan Constitution because the right to life would be meaningless without providing essential health care ${ }^{17}$.

An interesting comparison can be made with the constitution of Mozambique, another country, like Sri Lanka, that was subjected to a protracted civil crisis which led to millions of internally displaced persons. In Mozambique's Constitution, the articulation and enshrinement of the right to health within the Fundamental Rights, Duties And Freedoms of the Constitution, provides that "all citizens shall have the right to medical and health care, within the terms of the law, and shall have the duty to promote and preserve health"4. The Constitution clearly states that "medical and health care for citizens shall be organized through a national health service which shall benefit all Mozambicans". Thus the right to health is explicitly expressed within its constitution for citizens.

The Right to health is given a statutory recognition in numerous Statutory Rights ${ }^{\mathrm{v}}$ in Sri Lanka. The $13^{\text {th }}$ Amendment of Sri Lanka's Constitution (Certified on 14th November, 1987) devolves major elements of health care to Provincial and District level Government authorities, to especially promote more efficient administration by the local Authorities in relation to public health. As per the List I (Provincial Council List of $9^{\text {th }}$ Schedule) referred in Article $154 \mathrm{~A}$ of $13^{\text {th }}$ Amendment to the Constitution, "the establishment and maintenance of public hospitals, rural hospitals, maternity homes, dispensaries (other than teaching hospitals and hospitals established for special purposes); "Public health services, health education, nutrition, family health, maternity and child care, food and food sanitation, environmental health and Formulation and implementation of Health Development Plan and of the Annual Health Plan for the Province come under the purview of relevant Provincial councils. According to the Concurrent List (List III referred 13th Amendment of the Constitution), schools for training of Auxiliary Medical Personnel; the supervision of private medical care, control of

\footnotetext{
v Statutory rights are an individual's legal rights, given to
} him or her by the local and national ruling government. nursing homes and of diagnostic facilities within a Province; Population control and family planning and Constitution of Provincial Medical Boards are to be done by both parties". Other Subjects and Functions not Specified in List I or List III are reserved by the Central Government. These include such components as financial allocation of health budgets.

\section{The Sri Lankan Penal code}

Sri Lanka's criminal code is a document which compiles all, or a significant amount of, a particular jurisdiction's criminal law ${ }^{5}$ Typically a criminal code will contain offences which are recognized in the jurisdiction, penalties which might be imposed for these offences and some general provisions (such as definitions and prohibitions on retroactive prosecution. In Sri Lanka's Penal code 3 sections cite offences affecting the public health: Section 271. Making atmosphere noxious to health, Section 262. Negligent act likely to spread injection of any disease dangerous to life and Section 263. Malicious act likely to spread infection of any disease dangerous to life.

These sections make it punishable "to do a negligent or malicious act likely to spread infection of any disease dangerous to life". In addition, adulteration of foods, making atmosphere noxious to health, fouling the water of a public spring or reservoir, inter alia are made as offences under the Penal Code and also under the Food Act. Commentators have concluded that according to these provisions, "no doubt exists" as to the recognition of the statutory right regarding right to health ${ }^{6}$.

\section{Sri Lanka's Emergency Laws and implications for public health protection}

The Sri Lanka Penal Code does contain many provisions where the state can charge and prosecute individuals who are considered "enemies of the state and terrorists". Two additional sets of laws-the Public Security Ordinance 1947 (PSO), dating back to British colonial rule ${ }^{7}$, and the Prevention of Terrorism (Temporary Provisions) Act of 1979 (PTA)provides the state broad powers to hold individuals without charge or trial in violation 
of their basic due process rights ${ }^{8}$. The Prevention of Terrorism Act, enacted in 1979, allows arrests without warrant and permits detention without the suspect being produced before a court for up to 18 months.

The government formulated more than 20 new emergency regulations in 2005, following the assassination of the then Foreign Minister, Lakshman Kadirgamar. Two important emergency laws formulated in 2005 were: The Emergency (Miscellaneous Provisions and Powers) Regulation No. 1 of 2005 and the Emergency (Prevention and Prohibition of Terrorism and Specified Terrorist Activities) Regulation No. 7 of 2006, provide military personnel with sweeping powers of arrest and detention without regard to the fundamental rights protections provided by international law. The key features/powers to state activated by these two emergency laws may also allow for the detention of any person "acting in any manner prejudicial to the national security or to the maintenance of public order, or to the maintenance of essential services". The State may: a) Allow for detention of persons without charge for up to one year. This can be extended for an additional six months, or 18 months altogether. The Emergency Regulations provide for a detainee to be physically produced before a magistrate within 30 days (instead of within one day (24 hours) under the criminal procedure code); or b), Authorities need not submit a written record of arrest and detention to the court, or ensure the rights of detainees to be notified of the reasons for arrest or for detainees to have access to legal counsel ${ }^{\mathrm{vi}}$.

It is important to highlight in this discourse on health and human rights that the IDP camps were not managed under civilian administration (through the Government agent), rather by the Ministry of Defense (under the purview of a military officer titled "Competent Authority of IDP care"). Health care services within the IDP camps were however managed by the Ministry of Health under the guidance of the Minister of Health, Secretary of Health and under field operational leadership of Directorate of IDP Health Care. The competent authority for IDPs

\footnotetext{
vi Showing that important requirements of Sri Lankan law are not applicable under the emergency regulations.
}

restricted movement of displaced persons out of Menic Farm IDP camp during the first 6 months, permitting only those deemed severely ill requiring referral to specialized medical facilities, or those how had obtained special consent from authority to depart camp. Both international and local humanitarian agencies were also initially subjected to restricted movement/access into the IDP settings, although access to undertake interventions were granted to UN agencies and increased within 2 to 3 months of camp establishment. The rationale provided for such measures were that tight enforcement of camp movements were needed until LTTE cadres from within the displaced civilian population were identified and referred for Government rehabilitation and reintegration programs'. Emergency laws of Sri Lanka were invoked via parliamentary process, and other anti-terrorism legislation as ground for the state to undertake measures to isolate those 'enemies of the state'. The restrictions on civilian movements in and out of Menic Farm were lifted after this phase. Some advocacy groups termed such restrictions, to both humanitarian access and movement of IDPs' as 'unlawful', 10.

The Sri Lanka Penal Code contains many provisions where the state may indeed charge and prosecute individuals who are considered "enemies of the state and terrorists". The Prevention of Terrorism Act (PTA), enacted in 1979, allows arrests without warrant and permits detention without the suspect being produced before a court for up to 18 months .The government may hold a person under the PTA on suspicion and need not charge the person with an offense. The government formulated more than 20 new emergency regulations in 2005, following the assignation of Foreign Minister Lakshman Kadirgamar. Two important emergency laws formulated in 2005 were: The Emergency (Miscellaneous Provisions and Powers) Regulation No. 1 of 2005 and the Emergency (Prevention and Prohibition of Terrorism and Specified Terrorist Activities) Regulation No. 7 of 2006, provide military personnel with sweeping powers of search, arrest, and detention without regard to the fundamental rights protections provided by international law. Authorities need not submit a written record of arrest and 
detention to the court, or ensure the rights of detainees to be notified of the reasons for arrest or for detainees to have access to legal counsel. According to Human Rights Watch Report (HRW) of Sri Lanka in $2010^{\mathbf{1 0}}$, the emergency regulations of Sri Lanka are "vaguely worded" and claim to facilitate arbitrary arrest of suspects. Habeas corpus is a writ requiring a person under arrest to be brought before a judge or into court, especially to secure the person's release unless lawful grounds are shown for their detention ${ }^{11}$. Habeas corpus is an important aspect of human rights, and article 141 of the Sri Lankan constitution, provides for the right of habeas corpus ${ }^{\mathbf{1 2}}$. The HRW alleges that Sri Lanka Emergency Regulations violates article 141 of constitutional rights by allowing authorities to hold detainees in irregular places of detention, move a detainee from place to place for interrogation, and do not require the publication of a list of authorized places of detention $^{\mathbf{1 3}}$. The HRW report argues that the term "prejudicial to the national security" is not further defined and "could be interpreted to include peaceful or nonviolent acts protected under the rights to free expression or association".

In discussing the Right to Health as a Universal Human Right Norm, it becomes important to expand on the key international instruments and how they enshrine the right to health. International human rights law provides protections to individuals in custody during an internal armed conflict unless they are superseded by more specific provisions of humanitarian law. International humanitarian law (the laws of war) exists as international humanitarian law and human rights law, and are applicable during internal armed conflicts such as the conflict in Sri Lanka. Importantly, international human rights laws includes the International Covenant on Civil and political Rights (ICCPR) ${ }^{\mathbf{1 4}}$, which Sri Lanka ratified in 1980, and the Convention against Torture and Other Cruel, Inhuman or Degrading Treatment or Punishment ${ }^{15}$, the Convention on the Rights of the Child ${ }^{\mathbf{1 6}}$, and other sources of human rights law. Human rights can only be suspended in certain circumstances, such as during a declared state of emergency, where the State may temporarily derogate from (suspend) certain rights. Such suspension is subject to strict requirements outlined in the Siracrusa Principals. The ICCPR also permits states to suspend or restrict (derogation) certain rights during a state of emergency. There are however, a number of human rights that cannot be restricted in any circumstance including the right to life, as freedom from torture and slavery and freedom of thought, conscience and religion.

A UN report alleged serious human rights violations against the Government of Sri Lanka (labeled in media as the Darusman Report) and also in recent UNHRC debates on Sri Lanka, that the Sri Lankan government violated the fundamental human rights, including the right to be informed of specific reasons for arrest, the right to challenge the lawfulness of the detention before an independent judicial authority (habeas corpus), and the right of access to family members while the displaced population lived in Vavuniya IDP camps ${ }^{17}$. The Government of Sri Lanka maintained that the final assault on the LTTE in the Wanni region from early 2009 was based on 'humanitarian grounds'. The Government military spokespersons and the political leadership labeled the final conflict as a 'rescue mission' to ensure the protection of rights of those innocent civilians incarcerated by the LTTE". The State embraced the view that the assault was part of an obligation to protect civilian life and respect and fulfill the right to health, within their jurisdictions.

\section{Acts, policies and legislation relevant to upholding the right to health of IDPs in Sri Lanka}

a) Rehabilitation of Persons, Properties and Industries Authority Act, No. 29 of 1987- was drafted "to assist the owner of any affected property to repair and restore such property. Under the Act, the Government of Sri Lanka (GoSL) upholds the responsibility of creating an authority to assist in the repair, restoration, or rehabilitation of persons, properties industries. This act derives some elements from the Principles on Housing and Property Restitution for Refugees and Displaced Persons (Pinheiro Principles). 
b) Welfare Benefits Act, No. 24 of 2002 provides the necessary legal framework for the payment of welfare relief benefits and formulates the guidelines for a transparent selection process for welfare recipients.

\section{c) Mediation (Special Categories of Disputes)} Act, No. 21 of 2003 - this Act dictates the creation of arbitration boards for special categories of disputes, including those that relate to resettlement. Although most special categories are not clearly defined in the act, the authority created in the process upholds the responsibility of identifying and defining these special circumstances.

d) Sri Lanka Disaster Management Act, No. 13 of 2005 - called for the establishment of the National Council for Disaster Management, the Disaster Management Centre, and technical advisory committees, amongst other entities. These entities are responsible for the preparation, coordination, and management of disaster-related plans and programs.

e) The Tsunami (Special Provision) Act, No. 16 of 2005 and Registration of Deaths (Temporary Provision) Act, No. 17 of 2005 served in the pressing aftermath of the 2004 tsunami to address temporary and immediate coordination and distribution channels for humanitarian aid and relief.

f) The Geneva Conventions Act, No. 04 of 2006 - gives "effect to the first, second, third, and fourth Geneva Conventions on Armed Conflict and Humanitarian Law ${ }^{\mathbf{1 9}}$. Adherence to the obligations under the Geneva Conventions has a bearing on the status of Sri Lanka's IDPs, and the government is obligated under International Humanitarian Law in protecting the rights of civilians during times of war.

\section{g) National Child Protection Authority Act, No}

50 of 1998 - Recommends measures to address the humanitarian concerns relating to children affected by armed conflict and the protection of such children, including measures for their mental and physical wellbeing and their reintegration into society. A related, yet thematically different act is the Children and Young Persons Ordinance Act, which describes the age of legally entering workforce and conditions for child labour. It derives its formulate from the ILO convention with reference to child labour etc. ILO convention talks about the age of 14 years as the child labour age, and 14 to 18 is allowed but for 'non harmful jobs' which do not significantly impact on physical and mental development.

h) Mental Health Policy of Sri Lanka (2005), and the Mental Health Act of Sri Lanka, 2010 (currently submitted for Cabinet approval). The National Mental Health policy applies latest advances in mental health care and treatment, and reshaping more power to patients and for community based rather than institutional care. Whilst it does not explicitly mention IDPs, it acknowledges the fact that after protracted civil conflict, the need for community mental health services are even more pronounced. The policy principles articulate, the protection of "the human rights and dignity of people with mental illness' and for ensuring 'mental health services will be culturally appropriate and evidence based'.

i) Resettlement Authority Act, No. 09 of 2007decrees the "Establishment of an authority to be called the Resettlement Authority; to vest the Authority with the power to formulate a national policy and to plan, implement, monitor, and co-ordinate the resettlement of the internally displaced persons and refugees ${ }^{19}$. The Resettlement Authority Act has functions to ensure that resettlement or relocation of IDPs in a safe and dignified; and that IDPs are engaged in the development process of the country. The Act is limited in its protection of more recent IDP case loads, since it articulates the protection of those protracted IDPs (from 1983 to the 2006), and not the ones most recently displaced. The Act is also not intended to provide provisions for resettlement, rather 'to coordinate activities' of IDPs.

j) International Covenant on Civil and Political Rights Act of Sri Lanka No. 56 OF 2007- Is perhaps the most powerful Act in term of guaranteeing rights of IDPs, although it does not explicitly mention IDPs. Its power lies in the fact that it allows for the High Court to exercise jurisdiction over the enforcement of the human rights recognized under this Act. There is no such clause even in the 
Fundamental Rights chapter in the Sri Lankan Constitution. Technically, this Act provides leverage for securing rights for IDPs who are after all citizens of the State.

\section{k) National Migration Health Policy of 2013 -}

Provides emphasis on all forms of migrant and mobile populations, including those 'forced migrants' (as refugees and IDPs). The policy articulates an inter-ministry approach in ensuring the public health safety of the migrants, irrespective of irregular (undocumented) and regular status, and also ensure the public health of host population. The policy articulates a rights-based approach to health, and emphasizes State functions to ensure the right to heath is fulfilled via health assessment, border health interventions and reintegration of returnee migrants by health system, to name a few dimensions.

\section{l) National Action Plan for the Protection and} Promotion of Human Rights (2011 to 2016) Internal displacement violates civil and political as well as economic, social and cultural rights. There is a need to highlight internal displacement as a core human rights problem. It is not only a humanitarian issue that requires humanitarian response. Indeed a positive development the Government of Sri Lanka has taken, which some critiques may say symbolically, has been the launch of a National Action Plan for the Protection and Promotion of Human Rights (2011 to 2016). The plan was developed by a range of civil society, academic and government agencies between 2010 to 2011. The government strategy to improve the rights of IDPs has been further strengthened by the activities contained in the priority areas on IDPs articulated in a National Action Plan. The Ministry of Resettlement and the Ministry of Disaster Management are the main 'focal' departments are responsible for the implementation of the majority of recommendations for IDP rights, with support of the relevant line-ministries. While the Government of Sri Lanka has not chosen to adopt the GPID as a Government Policy for assisting IDPs affected by the conflict, it may be argued that the National Action Plan for the Protection and Promotion of Human Rights and other domestic policy instruments provide sufficient protections for IDPs by way of a nationally accepted action plan, where if implemented, may contribute in realization of the right to health.

\section{Other relevant instruments, protocols and groups}

A positive step taken by the Ministry of Health within one year of displaced persons entering Menic farm was the establishment of National Standard Operating Procedures and National Guidelines in Health Sector Disaster response. The guidelines were developed by the DPRU, the same unit that coordinated the health sector efforts, after extensive consultation from medical colleges, academia, UN agencies and NGOs. The detailed guidance notes encompass all aspects of disaster response and is now delivered as a modular course to help capacitate medical officers as humanitarian health sector focal points throughout the country. However as indicated by the $55^{\text {th }}$ and $65^{\text {th }}$ World Health Assembly Resolutions in encouraging health care workers and health system to systematically measure violence related incidents through its various typologies (explained in previous chapter) is still not mandated in the Ministry of Health plans. Better training of public health workers in undertaking conflict sensitive and culturally appropriate strategies for violence prevention and mitigation may serve to boost the existing National Standard Operating Procedures and National Guidelines in Health Sector Disaster response.

\section{Sri Lanka IDP Protection Working Group (IPWH)}

In Sri Lanka, an IDP Protection Working Group (IPWH) was established by UNHCR in 2006 to serve as an Inter-Agency forum to bring actors together to discuss protection issues related to the conflict, IDPs and returnees at a national level. The Working Group aims to strengthen collaboration between agencies, identify needs and gaps, and advise the Government of Sri Lanka) and UN Country Team on protection issues. The IDP Protection Working Group has strong links with IDP protection fora in the districts and reports on a regular basis. The IDP Protection Working Group's membership consists of both UN and non-UN actors ${ }^{20}$. The 
IDP Protection Working Group is chaired by UNHCR and reports periodically to the Inter Agency Standing Committee ('IASC') and Consortium of Humanitarian Agencies on protection issues. Despite the broad mandate of the IPWG, it is unclear how the group contributed to the humanitarian response that emerged following the resolution of military conflict in 2009. There is little documented evidence and references to the activities of the IPWH during this period.

\section{SUMMARY}

This paper aimed to provide a brief overview of the principles in relation to Right to Health for IDPs in Sri Lanka and how these are enshrined within domestic legal frameworks. To summarize, the right to health is enshrined under multiple policies and legal provisions. While the language varies across such documents, it is noted that three key concepts emerge across all international instruments: First, it is the State that has the responsibility to guarantee their citizens the right to adequate health. Secondly, the State has the responsibility to ensure that none of their citizens are deprived of this right by state action. Finally, these rights are guaranteed to all citizens, regardless of displacement status, race, religion, gender, age, or social standing in the community, or other status.

In this analysis of normative frameworks, it also becomes apparent that there are complex linkages between health and human rights (WHO, 2002). The right to health is interrelated with, and expressed implicitly and explicitly in numerous articles. To speak of health in isolation of other rights then becomes futile. These inter-relationships, as graphically presented in Figure 1, show the protection of specific rights of IDPs during disasters and their connection with the normative frameworks. Therefore the right to health operates directly or indirectly as a prerequisite to all other human rights recognized in treaties. To deny someone health care is to deny or damage all that individual's rights. Without health, individuals are denied their right to be contributing members of the community and to provide for their families. Individuals who lack adequate health care can thus lose some or all ability to exercise fully the civil, political, economic, social, and cultural rights they possess. As Perrin in his analysis of The Right to Health in Armed Conflict articulates, the protection of the right to health requires the complement of the entire legal framework; "While IHL integrates specific considerations, striking a balance between humanitarian considerations and military necessity, human rights law remains relevant to complement IHL in order to fill the potential gaps" (Perrin, 2009).

\section{Ensuring IDP health protection beyond acute phases}

Many studies have shown that long after the 'last bullet is fired' from the barrel of a gun, the health consequences of war linger on. They linger not only in the buried landmines that result in blast injuries even decades after the peace-accords are signed, but as traumatic events buried within scarred minds, and at the most fundamental level of our genes. Solana (2006) argues that, "when crises are being resolved long term health issues are addressed last. Public health policy is thus seldom thought of in human security terms'. Well into periods of lasting peace, the contaminants of war such as landmines and UXOs continue to kill and maim civilian populations. The constant displacement, both as internally displaced persons or as refugees fleeing the state boundaries, leads to disruptions in vaccination campaigns, micronutrient supplementation programs, and other public health efforts. The 'downstream' impact of such chronic nutritional deficiencies may also lead to abnormal child growth outcomes (Gluckman, 2007). Generational impacts can also be seen in children born to underweight mothers, where stunting (height-for-age) and poor cognitive function development may also occur. The "fetal programming hypothesis," also known as the "developmental origins of health and disease" suggests that conditions very early in human development, even in utero, can leave lasting imprints of an organism's physiology, imprints that may 'affect susceptibility to diseases' with onsets that may occur many decades later (Gluckman, 2007). 
A seminal study by Susser and colleagues (1998) on the follow-up of children conceived during the Nazi occupation of Holland at the end of World War II implicated fetal stress to poor psychiatric outcomes later in adult life . Also called the "Dutch Hunger children study", the research provided a natural experiment in which pregnant women, along with the rest of the civilian population, were subjected to extreme food deprivation during a relatively discrete period of conflict (Terry, 2001). There was clearly a statistically significant elevation of risk of schizophrenia and related disorders among those whose mothers went through the peak of the famine during their second trimester of pregnancy (Brown, 2000). These findings have also been validated in other studies of individuals born during times of hunger and famines in China (St Clair, 2005). The affect chronic stress has on reshaping the human genome has also been revealed in Nobel Prize winning research (Epel, 2004). Evidence suggests that prolonged psychological stress not only influences disease processes and cellular immunity but also affect molecules that play a key role in aging. The implications of these research findings to those war affected populations that have experienced significant chronic stress through protracted conflicts and multiple displacements are yet to be explored.

These findings bring new insights and challenges into the 'ripple effect' on human health, development and wellbeing long after the resolution of conflict. Therefore, even though the 'right to health' may be realized for those displaced during the period of their stay in IDP camps, there fact that there are longitudinal consequences pertaining to health protection is of significant value, and a one often overlooked by health authorities, aid health agencies and human rights activists. It is argued that health systems need to account for and addressing such effects in health policy and planning following a humanitarian crisis.
From this analysis of the domestic legal framework that Sri Lanka has a somewhat robust and well articulated means of ensuring protection of those displaced. There appears to be sufficient provision for the fulfillment for the rights to health for IDPs despite the fact that the right to health is not enshrined as a Fundamental Right Sri Lanka's Constitution. The perpetual challenge then remains in the implementation of such Acts, Regulations and Policies; and also in the attitudes and determination of the state which views and values sovereignty over domestic affairs over international law. Concepts of sovereignty tend to be socially and politically conditioned and is therefore not static. Some states clinic to the notion of absolute power at domestic level. 


\section{REFERENCES}

1. United Nations Guiding Principles on Internal Displacement.

2. IDMC (2009) Internal Displacement: Global Overview of Trends and Developments in 2009. Geneva: Internal Displacement Monitoring Centre

3. Framework for National Responsibility in Addressing Internal Displacement

4. Mozambique Constitution: Fundamental Rights, Duties And Freedoms, Chapter 1. General Principles.

5. Sri Lanka Penal Code

6. Dissanayake, S (2009) "Right to Health" of Internally Displaced Persons, Human Rights Commission of Sri Lanka.

7. Public Security Ordinance (PSO), No. 25 of 1947.

8. Prevention of Terrorism (Temporary Provisions) Act, No 48 of 1979.

9. Dharmawardhane, I. (2013). Sri Lanka's PostConflict Strategy: Restorative Justice for Rebels and Rebuilding of Conflict-affected Communities. Perspectives on Terrorism, 7(6).

10. Human Rights Watch (2010). Legal Limbo. HRW publications.USA. Feb, 2010

11. Oxford English Dictionary, source: http://oxforddictionaries.com/definition/habeas+co rpus

12. Constitution of the Democratic Socialist Republic of Sri Lanka, Article 141, available athttp://www.priu.gov.lk/Cons/1978Constitution/I ndex.html.
13. Emergency Regulation of 2005, regulation 19 (3), 21, 49, and 69 (2).

14. International Covenant on Civil and Political Rights (ICCPR), G.A. res. 2200A (XXI), 21 U.N. GAOR Supp. (No. 16) at 52, U.N. Doc. A/6316 (1966), 999 U.N.T.S. 171, entered into force Mar. 23, 1976

15. Convention against Torture and Other Cruel, Inhuman or Degrading Treatment or Punishment, G.A. res. 39/46, annex, 39 U.N. GAOR Supp. (No. 51) at 197, U.N. Doc. A/39/51 (1984), entered into force June 26, 1987.

16. Convention on the Rights of the Child (CRC), G.A. res. 44/25, annex, 44 U.N. GAOR Supp. (No. 49) at 167, U.N. Doc. A/44/49 (1989), entered into force Sept. 2, 1990.

17. United Nations (2011) Report of the Secretary Generals panel of experts on Sri Lanka. UN publications. Source: www.un.org/News/dh/infocus/Sri_Lanka/POE_Re port_Full.pdf

18. Parliament of the Democratic Socialist Republic of Sri Lanka. Geneva Conventions Act, No. 4 of 2006.

19. Parliament of the Democratic Socialist Republic of Sri Lanka, Resettlement Authority Act, No. 09 of 2007.

20. Sri Lanka IDP Protection Working Group, Protection Advocacy Strategy (2008).Available at: http://www.hpsl.lk/docs/protection/ IDP $\% 20 \mathrm{P} \% 20 \mathrm{WG} \% 20$ Advocacy $\% 20$ Strategy $\% 20$ 2008_1.pdf 